\title{
AN ENVIRONMENTAL NOISE STUDY IN THE INDUSTRIAL, COMMERCIAL, RESIDENTIAL AREAS AND ARTERIAL ROADS IN WESTERN BOGOTA, COLOMBIA
}

\section{UN ESTUDIO DE RUIDO AMBIENTAL EN EL SECTOR INDUSTRIAL, ÁREAS COMERCIALES, RESIDENCIALES Y ARTERIALES EN EL OESTE DE BOGOTÁ, COLOMBIA}

\author{
Fredy Alejandro Guevara Luna ${ }^{1}$ \\ Marco Andrés Guevara Luna ${ }^{2}$ \\ ${ }^{1}$ Departamento de Ingeniería Química y Ambiental, Universidad Nacional \\ de Colombia. Bogotá, Colombia. \\ ${ }^{2}$ Departamento de Ingeniería de Procesos, Smart \& Simple Engineering - S\&SE S.A.S., Bogotá, Colombia; \\ Escuela de Ciencias Agrícolas, Pecuarias y del Medio Ambiente (ECAPMA), Universidad Nacional \\ Abierta y a Distancia (UNAD) Bogotá, Colombia. \\ ${ }^{1}$ marco.guevara@unad.edu.co
}

\begin{abstract}
Noise pollution as byproduct of development and urban activity is related with a great amount of economical, social and cultural variables, whose importance as stressing, and possible even dangerous agent in human life has come to be recognized in the last decades. In this case the megacity of Bogotá is the capital of Colombia, located in the center of the country. Bogotá is a very variable city in terms of economical and social level location, and even use of soils in the city planning. The factors mentioned above makes Bogotá a very complex analysis system for sound and noise pollution studies. Due to the size of the city, in this study the western area of the capital district was analyzed through sound measurements in 7 sites selected by types of areas, involving commercial, transportation, industrial,

residential and arterial roads. The main objective of this study was to identify the most important noise sources in the western area of the city. This study allowed to identify the arterial roads as one important source of noise in the city, possibly due to the traffic or heavy vehicles inside the city. The maximum harmful levels of sound reach values of about $85 \mathrm{~dB}$ in the mentioned locations (Ciudad de Cali avenue, Cll 13 avenue arterial roads and Salitre - El Greco Transmilenio Station), exceeding the permitted limits of $75 \mathrm{~dB}(\mathrm{~A})$ according to the local environmental standards.

Keywords: Noise pollution, environmental noise, public health, sound measuring, environmental policies.
\end{abstract}




\section{Resumen}

La contaminación acústica como subproducto del desarrollo y la actividad urbana está relacionada con una gran cantidad de variables económicas, sociales y culturales, cuya importancia como agente estresante, e incluso peligroso, en la vida humana ha llegado a ser reconocida en las últimas décadas. En este caso, la megaciudad de Bogotá es la ciudad capital de Colombia, ubicada en el centro del país. Bogotá es una ciudad muy variable en términos de ubicación de nivel económico y social, y uso de suelos en la planificación de la ciudad. Los factores mencionados anteriormente hacen de Bogotá un sistema de análisis muy complejo para estudios de contaminación acústica y sonora. Debido al tamaño de la ciudad, en este estudio se analiza el área occidental del distrito capital a través de mediciones sonoras en 7 diferentes tipos de áreas seleccionadas, que incluyen carreteras comerciales, de transporte, industriales, residenciales y arteriales. El objetivo principal de este estudio es identificar las fuentes de ruido más importantes en el área occidental de la ciudad. Este estudio permitió identificar las carreteras principales como una importante fuente de ruido en la ciudad, posiblemente debido principalmente al tráfico de vehículos pesados en el interior. Los niveles máximos y dañinos de sonido alcanzan valores de aproximadamente $85 \mathrm{~dB}$ en los lugares mencionados (Av. Ciudad de Cali, Av. Cll 13 vías arteriales y Salitre - Estación El Greco Transmilenio), excediendo los límites permitidos de $75 \mathrm{~dB}(\mathrm{~A})$ de acuerdo con las normas de regulación de las autoridades ambientales locales.

Palabras Clave: Contaminación acústica, ruido ambiental, salud pública, medición sana, políticas ambientales.

\section{Introduction}

New advances in sciences and technology have large impacts in the society. Those impacts go through economic, cultural, health and social issues. However, progress also entails some significant drawbacks that would be preferably avoided, or at least minimized. One such case is noise pollution, whose importance as stressing, and possible even dangerous, agent in human life has come to be recognized in the last decades (Barrigón Morillas, Gómez Escobar, Méndez Sierra, Vílchez Gómez, \& Trujillo Carmona, 2002; de Noronha Castro Pinto \& Moreno Mardones, 2009; Hunashal \& Patil, 2012; Silva \& Mendes, 2012; USEPA - US Environmental Protection Agency, 1978; Zannin, Diniz, \& Barbosa, 2002). Regarding noise pollution in large cities several impacts in human health, and finally public health, have been clearly identified and studied. Also impacts of noise levels over animals and local species such as birds have been identified before (Francis, Kleist, Ortega, \& Cruz, 2012; Istrate, Oprea, Rada, \& Torretta, 2014; Ortega, 2012).

The effect of noise pollution in different location all over the globe deeply depends of several variables: level of development, total population and population density, kind of activities involved, culture, local habits, geographic location, soil usage, etc. the factor described above make necessary to characterize carefully the site and the situation under the study (Barrigón Morillas et al., 2002; Fiedler \& Zannin, 2015; Silva \& Mendes, 2012).

Bogotá is the capital of Colombia, located in the center of the country. It is one of the densest cities in Colombia with 10,700,000 inhabitants 
in the metropolitan area, in a surface extension of $1,580 \mathrm{~km}^{2}$ (DANE, 2006). Bogotá is a very variable city in terms of economical and social level location, and land use of in the city planning (Ramírez et al., 2018). Even when Bogotá has regulations and public administration entities in charged of monitoring the noise pollution emissions (Secretaria Distrital de Ambiente, 2006, 2010a, 2010b), there is concern about the actual situation of the city in noise levels aspects and other contamination forms of the environment (Ramírez, Mura, \& Franco, 2017).

Factors mentioned above makes Bogotá a very complex system to be taken as object of study in any technical field, in this case sound and noise pollution. Due the size of the city, in this study the western area of the city was analyzed through sound measurements in 7 different selected types of areas, involving commercial, transportation, industrial, residential and arterial roads.

The main goal of this study was to define the noise levels in the western region of the Bogotá capital city for 3 types of locations: commercial (Gran estación and Diverplaza), transportation (Salitre- El Greco Transmilenio station), industrial areas, residential and arterial roads (Av. ciudad de Cali and Av. Cll 13). Other important target of this research was to identify the most important noise sources in the locations established for the study founding the base for further researches and stimulating actions by the local public regulation institutions.

This research was performed using measurements for the 7 selected locations of the city region during 30 minutes, according to the established procedures by the local authorities standards, for selected dates (Secretaria Distrital de Ambiente, 2006). Sonometer CIRRUS 162-B CLASS 2 was used.
This first study allowed to identify the arterial roads as one important source of noise in the city, possibly mainly due to the traffic or heavy vehicles inside the city. The maximum harmful levels of sound reached values of about $85 \mathrm{~dB}$ in the mentioned locations (Av. Ciudad de Cali, Av. Cll 13 arterial roads and Salitre - El Greco Transmilenio Station) exceeding the permitted limits of $75 \mathrm{~dB}(\mathrm{~A})$ according to the environmental local authorities regulation standards (Francis et al., 2012; ISO, 2003, 2007, Secretaria Distrital de Ambiente, 2006, 2010a, 2010b; USEPA - US Environmental Protection Agency, 1978).

\section{Methods}

There are extensive studies regarding methods to study the sound levels in cities with different characteristics. In this case the size of the City makes necessary the use of an specific approach suggested by Brown and Lam (Brown, 1991; Brown \& Lam, 1987). This strategy was described based on the selection of sampling points using a suitable classification of the urban noise and the location where it will be measured.

Approach mentioned has been implemented successfully in previous researches (de Noronha Castro Pinto \& Moreno Mardones, 2009; Hunashal \& Patil, 2012).

Based on this principle of sampling for the development of the study, the western area of the city was selected and inside this area 7 places were chosen as sampling points for the measurements during 30 minutes, according to the established procedures by the local authorities standards, for selected dates (Secretaria Distrital de Ambiente, 2006). These standards establish a maximum noise level allowed according to the local soil usage, for the areas under study the maximum value is $75 \mathrm{~dB}(\mathrm{~A})$, and the minimum measuring time is 15 minutes. 
Data processing was performed using Python $®$ version 3.6 (Anaconda Python, n.d.). The Spyder IDE was the graphical user environment for the code development.

\section{Places}

Based on the method described before for the noise study, the 7 sampling sites are shown in
(Figure 1) and their coordinates are tabulated in (Table 1). The selected sampling points were located in zones of normal exposure of people. Also, all locations are in exterior-public sites with a great people traffic and concurrency in normal hours during the day, and particularly in the sampling hour.

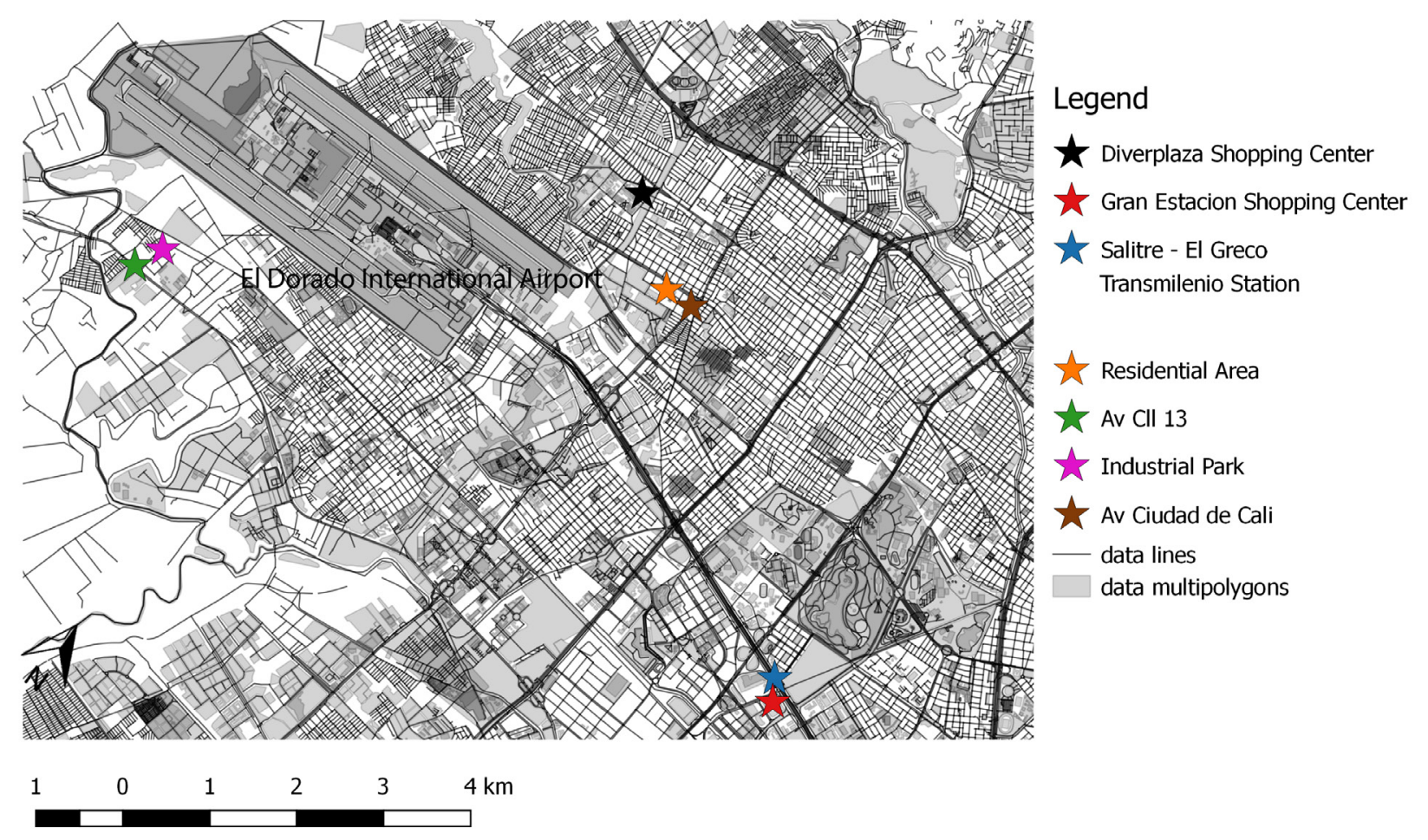

Figure 1. Measuring points location for this study according to the analysis strategy defined (This Research).

\section{Measuring instrument}

The sonometer used for this study was the CIRRUS 162-B CLASS 2 (CIRRUS Research plc, 2017). Universidad Nacional de Colombia supplied the measuring equipment. Technical personal from the institution performed the calibration of the equipment in January 2017, using the kit provided by CIRRUS.

\section{Measuring procedure}

The instrument was put on the tripod for data collection (Figure 2). All measurements were made on Monday at 11:00 am per 1800 seconds (30 minutes). Description about the sites is summarized in Table 1. 


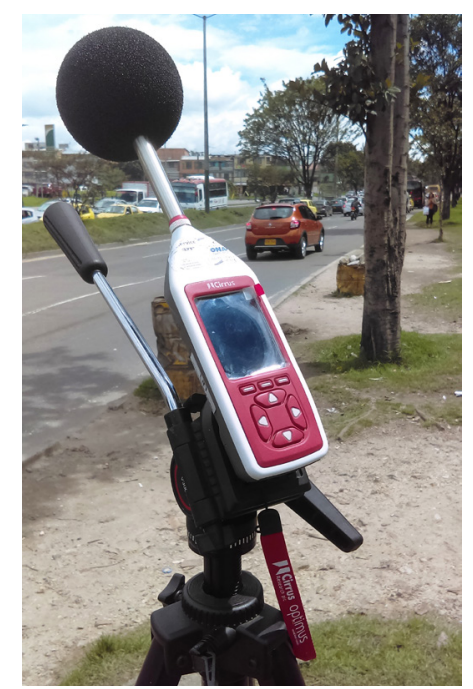

Figure 2. Measuring instrument in Ciudad de Cali Avenue (CIRRUS Research plc, 2017)

Table 1. Measured sound data summary, and geographical locations.

\begin{tabular}{l|c|c|c|c|c|c|c}
\hline \multirow{2}{*}{ Location } & \multicolumn{2}{c}{ Loordinates } & \multicolumn{5}{c}{ LAeq dB(A) } \\
\hline $\begin{array}{l}\text { Av. Ciudad de Cali } \\
\text { arterial road }\end{array}$ & 4.68906 & -74.11007 & $16 / 01 / 2017$ & 72.465 & 85.140 & 56.340 & 5.582 \\
\hline \begin{tabular}{l} 
Industrial area \\
\hline Av. Calle 13
\end{tabular} & 4.69494 & -74.16471 & $23 / 01 / 2017$ & 52.224 & 61.930 & 47.350 & 2.455 \\
\hline $\begin{array}{l}\text { arterial road } \\
\text { Residential Area }\end{array}$ & 4.69327 & -74.16759 & $30 / 01 / 2017$ & 75.124 & 83.100 & 66.220 & 3.496 \\
\hline $\begin{array}{l}\text { Salitre- El Greco } \\
\text { Transmilenio Station }\end{array}$ & 4.65060 & -74.10145 & $13 / 02 / 2017$ & 76.823 & 87.130 & 65.930 & 4.160 \\
\hline $\begin{array}{l}\text { Commercial area } \\
\text { Gran Estación } \\
\text { Shopping Center }\end{array}$ & 4.64816 & -74.10165 & $20 / 02 / 2017$ & 62.300 & 73.000 & 56.320 & 3.385 \\
\hline $\begin{array}{l}\text { Commercial area } \\
\text { Diverplaza } \\
\text { Shopping Center }\end{array}$ & 4.70073 & -74.11513 & $27 / 02 / 2017$ & 69.952 & 81.260 & 58.450 & 3.675 \\
\hline
\end{tabular}

\section{Results and discussion}

The data collected in the 7 different sites along the western region of Bogotá is summarized in (Table 1). The data considered corresponds to the LAeq levels measured by the instrument. Data saved by the memory log of the measurement instrument have a temporal resolution of $1 \mathrm{~s}$.

The data collected showed notable mean and maximum high levels for arterial vehicular roads and the transportation station (Ciudad de Cali Avenue, CII 13 Avenue arterial roads and Salitre - El Greco Transmilenio Station). The mean levels were above $70 \mathrm{~dB}$ for LAeq, which are normal levels of noise in public sites. Even so, for these locations mentioned the maximum sound levels reached values of $85.140,83.100$ and $87.130 \mathrm{~dB}(\mathrm{~A})$ respectively, that means these places are reaching harmful levels of noise with possible sensible effects in the public health of the population of this part of the city. 
The peaks of the sound levels during the data sampling can be better observed graphically, the (Figure 3) (Anexo) shows the time series of the LAeq sound levels for the 7 sampling sites. There are notable peaks observed in all sites, but the scale of the arterial vehicular roads and the transportation station mentioned have considerable higher values of maximum levels. These observations permit to correlate the presence of vehicular activity with high noise levels, even with greater impact than the industrial area in this case.

The qualitative comparation of the noise levels in the sampling points is shown in the contour maps of noise levels (Figure 4). Again, the levels of noise for the locations mentioned before were higher in comparison as expected. The commercial and residential areas had normal sound levels, even when the noisy locations are close in spatial terms.
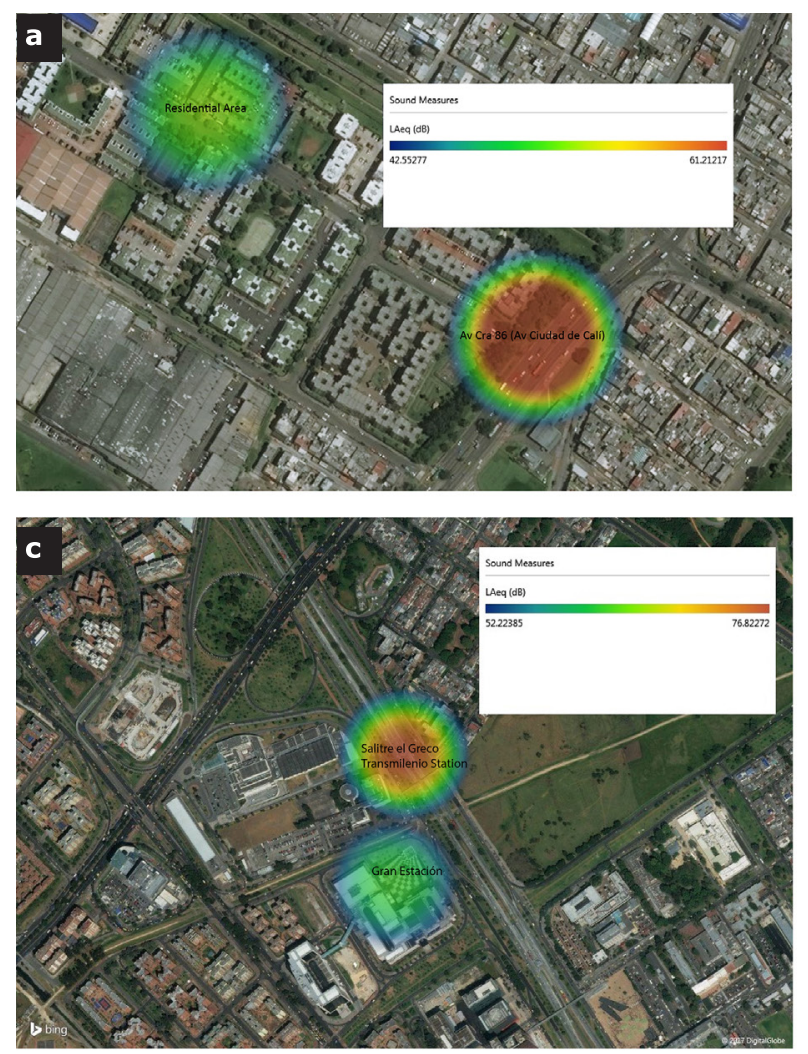

In this case, the industrial area had relatively low noise levels possibly due to low working intensity in the plants the day of the measurement. It is natural to expect higher sound levels in this type of area, further studies and measuring campaigns can bring additional data and results to take better planning decisions about the location of this kind of areas and its impacts. In addition, studies indoor in the commercial areas are necessary to analyze the particular situations inside shopping centers in Bogotá.

The arterial road in this study have the particular feature of high proportion of heavy vehicles in traffic. This aspect makes important the roads in terms of noise and atmospheric pollutants to the areas inside the city, and the effects in the population (Fiedler \& Zannin, 2015; Pathak, Tripathi, \& Mishra, 2008; Ramirez \& Dominguez, 2013)
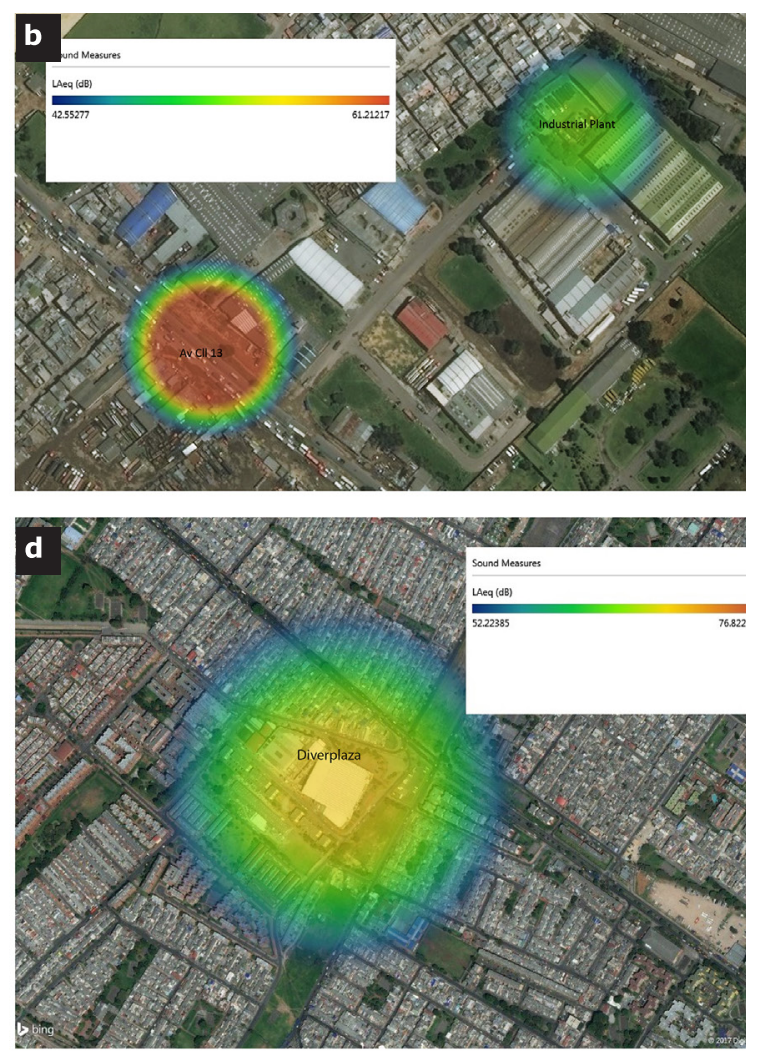

Figure 4. Sound Maps (LAeq units in $\mathrm{dB}(\mathrm{A})$ ): a) Ciudad de Cali Avenue road and Residential area, b) Industrial area and CII 13 Avenue road, c) Transmilenio Salitre - El Greco station and Commercial Area Gran Estacion shopping center, d) Commercial area Diverplaza shopping center. 


\section{Conclusions}

The sound levels of 7 different places were measured and summarized in this study. The sound levels measured were compared between them and with the harmful levels standard regulation values as $75 \mathrm{~dB}(\mathrm{~A})$ (Secretaria Distrital de Ambiente, 2006), and its implications in human health. The arterial vehicular roads and the transportation station (Ciudad de Cali Avenue, CII 13 Avenue arterial roads and Salitre - El Greco Transmilenio Station) were the location with higher levels of noise, in terms of peaks for the maximum and mean measurements. For these locations, the maximum sound levels reached values of 85.140 , 83.100 and $87.130 \mathrm{~dB}$ respectively, the mean values are about $70 \mathrm{~dB}$ lightly under the maximum allowed level.

For data collected, standard deviations between 3.385 and $5.582 \mathrm{~dB}(\mathrm{~A})$ were obtained. These variability means that the sound levels trend to be stable at the mean values for each dataset. The location with the higher variability is the residential area, and the location with the lower variability is the commercial area.

The maximum values measured of about $85 \mathrm{~dB}$ are high enough to be harmful and affect negatively people health, and therefor affect the public health aspects of the city. These high levels can be related with the strong presence of heavy vehicles in the traffic roads inside the city. The regulations of heavy vehicles traffic inside the city must be regulated to mitigate problems of noise pollution taking this study as part of the technical evidence, and other issues regarding atmospheric contamination can be improved as well. In addition, negative impact of high noise levels in public health will generate economic loses to public budged of the city.

Further studies in another city places are required to observe and understand the complete phenomena in relation with noise pollution. This study was developed in outdoor environments, will be also important to investigate about noise pollution indoor for many common environments of the city, such as: shopping centers, schools, hospitals, offices, and bus terminal stations. The results obtained can be useful for public administration entities in the future to make a suitable planning of the use of different areas inside the city and in its surroundings.

El Dorado International Airport was not considered in this case, but it will be interesting to consider the contribution of aircraft traffic in the situation of the city noise pollution nowadays and in the future.

\section{Acknowledgements}

Authors thanks to S\&SE S.A.S (Smart and Simple Engineering S.A.S) in Colombia for financing this project and support this innovation environment since the very beginning, and the Universidad Nacional de Colombia for providing the measuring instrument and technical assistance for the development.

\section{Cited literature}

Barrigón Morillas, J. M., Gómez Escobar, V., Méndez Sierra, J. A., Vílchez Gómez, R., \& Trujillo Carmona, J. (2002). An environmental noise study in the city of Cáceres, Spain. Applied Acoustics, 63(10), 1061-1070. https://doi.org/10.1016/ S0003-682X(02)00030-0

Brown, A. L. (1991). Urban Noise Urban Noise, 50, 1-5.

Brown, A. L., \& Lam, K. C. (1987). Levels of ambient noise in Hong Kong. Applied Acoustics, 20(2), 85-100. https://doi.org/10.1016/0003682X(87)90056-9

CIRRUS Research plc. (2017). Optimus Red Sound Level Meters for Occupational Noise Measurements. Retrieved July 4, 2017, from http://www. cirrusresearch.co.uk/products/sound-level-meters/optimus-red-sound-level-meters/ 
De Noronha Castro Pinto, F. A., \& Moreno Mardones, M. D. (2009). Noise mapping of densely populated neighborhoods - Example of Copacabana, Rio de Janeiro - Brazil. Environmental Monitoring and Assessment, 155(1-4), 309-318. https://doi. org/10.1007/s10661-008-0437-9

Fiedler, P. E. K., \& Zannin, P. H. T. (2015). Evaluation of noise pollution in urban traffic hubs-Noise maps and measurements. Environmental Impact Assessment Review, 51, 1-9. https://doi. org/10.1016/j.eiar.2014.09.014

Francis, C. D., Kleist, N. J., Ortega, C. P., \& Cruz, A. (2012). Noise pollution alters ecological services : enhanced pollination and disrupted seed dispersal. Proceedings of the Royal Society B, 279(March), 2727-2735. https://doi.org/10.1098/ rspb.2012.0230

Hunashal, R. B., \& Patil, Y. B. (2012). Assessment of Noise Pollution Indices in the City of Kolhapur, India. Procedia - Social and Behavioral Sciences, 37, 448-457. https://doi.org/10.1016/j.sbspro.2012.03.310

ISO. (2003). Acoustics - Description, measurement and assessment of environmental noise. Part 1: Basic quantities and assessment procedures (ISO 1996-1:2003).

ISO. (2007). Acoustics - Description, measurement and assessment of environmental noise. Part 2: Determination of environmental noise levels (ISO 1996-2:2007).

Istrate, I. A., Oprea, T., Rada, E. C., \& Torretta, V. (2014). Noise and air pollution from urban traffic. The Sustainable City, 191, 1381-1389. https:// doi.org/10.2495/SC141162

Ortega, C. (2012). Effects of Noise Pollution on Birds: A Brief Review of Our Knowledge. Ornithological Monographs, 74(1), 6-22. https:// doi.org/10.1525/om.2012.74.1.6.6

Pathak, V., Tripathi, B. D., \& Mishra, V. kumar. (2008). Evaluation of traffic noise pollution and attitudes of exposed individuals in working place. Atmospheric Environment, 42(16), 3892-3898. https://doi.org/10.1016/j.atmosenv.2007.12.070

Ramirez, A., \& Dominguez, E. (2013). Modeling urban traffic noise with stochastic and deterministic traffic models. Applied Acoustics, 74(4), 614-621. https://doi.org/10.1016/j.apacoust.2012.08.001

Ramírez, O., Mura, I., \& Franco, J. F. (2017). How Do People Understand Urban Air Pollution? Exploring Citizens' Perception on Air Quality, Its Causes and Impacts in Colombian Cities. Open Journal of Air Pollution, 6(1), 1-17. https://doi. org/10.4236/ojap.2017.61001

Secretaria Distrital de Ambiente. (2006). Resolucion 0627 De 2006. Bogotá: Secretaría General de la Alcaldía Mayor de Bogotá D.C. Retrieved from http://www.alcaldiabogota.gov.co/sisjur/ normas/Norma1.jsp?i=19982

Secretaria Distrital de Ambiente. (2010a). Resolución 6918 de 2010. Bogotá: Secretaría General de la Alcaldía Mayor de Bogotá D.C.

Secretaria Distrital de Ambiente. (2010b). Resolución 6919 de 2010. Bogotá: Secretaría General de la Alcaldía Mayor de Bogotá D.C.

Silva, L. T., \& Mendes, J. F. G. (2012). City Noise-Air: An environmental quality index for cities. Sustainable Cities and Society, 4(1), 1-11. https://doi. org/10.1016/j.scs.2012.03.001

USEPA - US Environmental Protection Agency. (1978). Protective noise levels. Condensed version of EPA levels document. Washington, DC.

Zannin, P. H. T., Diniz, F. B., \& Barbosa, W. A. (2002). Environmental noise pollution in the city of Curitiba, Brazil. Applied Acoustics, 63(4), 351-358. https://doi.org/10.1016/S0003$682 \times(01) 00052-4$ 